\title{
INTEGRASI PASAR BERAS INDONESIA DENGAN PASAR BERAS INTERNASIONAL
}

\author{
Prof. Catur Sugiyanto, Ph.D ${ }^{l}$ dan Dr. Soetatwo Hadiwigeno ${ }^{l}$ \\ ${ }^{\text {I}}$ Fakultas Ekonomika dan Bisnis \\ Universitas Gadjah Mada
}

Artikel diterima Mei 2012

Artikel disetujui untuk dipublikasikan Desember 2012

\begin{abstract}
The food crisis that was triggered by climate change has swept the world lately. Climate change is affecting the pattern of the world that led to changes in the pattern of agricultural production as well. Changes in the pattern of production results in world food production schedule was delayed, and along with these changes, many countries export so that world food prices increase. Rising world food prices starting from US and then spread in the other parts of the world, including Indonesia. However, it is unknown how big relatedness of International food prices changes with food prices in Indonesia.

This paper aims to analyze the connectedness between domestic rice market with international market, how long shock in international rice impact on the domestic market and to analyze interlinkage in domestic primary rice market.

Using data rice price in indonesia and international rice price of FAO, writer found that market rice integrated both in domestic and foreign, so the fluctuations in both markets would affect each other

Keywords: Food Crisis, Production Pattern, Domestic and International Market Integration

ABSTRAK

Krisis pangan yang dipicu oleh perubahan iklim telah melanda dunia belakangan ini. Perubahan iklim mempengaruhi pola musim dunia sehingga menyebabkan terjadinya perubahan pola produksi pertanian juga. Perubahan pola produksi tersebut menyebabkan jadwal produksi bahan pangan dunia tertunda, dan seiring dengan perubahan tersebut, banyak negara ekspor sehingga harga pangan dunia meningkat. Meningkatnya harga pangan dunia dimulai dari US dan kemudian merambah ke belahan dunia lain, termasuk Indonesia. Namun, tidak diketahui seberapa besar keterkaitan perubahan harga pangan Internasional dengan harga pangan di Indonesia.

Paper ini bertujuan untuk menganalisis sifat keterkaitan antara pasar beras domestik dengan pasar internasional, berapa lama syok di beras internasional berpengaruh terhadap pasar domestik, dan untuk menganalisis keterkaitan pasar beras utama di dalam negeri.

Dengan menggunakan data harga beras di Indonesia dan harga beras Internasional dari FAO, penulis menemukan bahwa pasar beras terintegrasi, baik di dalam negeri maupun dengan luar negeri, sehingga setiap fluktuasi di kedua pasar akan saling berpengaruh.
\end{abstract}

Kata Kunci: Krisis Pangan, Pola Produksi, Integrasi Pasar Domestik dan internasional

\section{PENDAHULUAN}

Krisis pangan telah melanda dunia akhir-akhir ini. Salah satu pemicu krisis tersebut adalah perubahan iklim. Perubahan iklim berpengaruh terhadap perubahan pola produksi, produksi tertunda atau turun produktivitasnya, sementara permintaan relatif tetap. Akibatnya terjadi gap produksi yang cukup besar. Kondisi tersebut dibarengi dengan perubahan cuaca akibat pemanasan global (global warming) yang merubah pola musim dunia sehingga jadwal produksi pertanian musiman berubah. Produksi bahan pangan dunia berkurang (tertunda), banyak negara produsen membatalkan ekspor sehingga harga pangan dunia meningkat. 
Kenaikan harga pangan dunia dimulai dari kenaikan harga jagung di US, diikuti kenaikan harga kacang-kacangan yang kemudian merambah sampai ke Indonesia dan juga berbagai belahan dunia yang lain. Kenyataan ini membuktikan adanya keterkaitan antara fluktuasi pasar di dalam negeri dengan fluktuasi harga di luar negeri. Apa yang terjadi di US segera berpengaruh terhadap kondisi di dalam negeri. Namun demikian, tidak diketahui seberapa besar keeratan hubungan antara pasar pangan di dalam negeri dengan pasar pangan internasional, apakah pasar dalam negeri dipengaruhi pasar luar negeri (lag) ataukah bisa kebalikannya (lead)? Berapa lama syok (shock) di pasar luar negeri berpengaruh terhadap pasar di dalam negeri? Tanpa informasi mengenai sifat keterkaitan dan kapan pengaruh syok akan efektif, menyebabkan pelaku ekonomi kehilangan kesempatan memperoleh keuntungan dari perdagangan internasional (gains from trade) dan pengambil kebijakan tidak akan akurat dalam menentukan kebijakan. Ketidakakuratan tersebut menyebabkan kesejahteraan masyarakat tidak optimal.

Berbagai penelitian mengenai keterkaitan antar pasar telah banyak dilakukan. Beberapa peneliti menganalisis keterkaitan pasar dalam konteks keterkaitan harga dengan menggunakan basis hukum harga tunggal (the Law of One Price), misalnya (Ardeni, 1989; Baffes, 1991) atau dalam konteks integrasi pasar (Ravallion, 1986; Sexton et al, 1991; Palaskas and Harriss 1993; Zanias, 1993; Gardner and Brooks, 1994; Blauch 1997). Hasil estimasi dari kedua pendekatan di atas mampu mendeteksi arah dan besaran keterkatian antar pasar, baik domestik maupun internasional. Dalam analisis, peneliti-peneliti tersebut menggunakan metode kuantitatif yang berbeda-beda, seperti korelasi, persamaan tunggal, maupun sistem persamaan. Pilihan terhadap metode yang dipergunakan tergantung kasus yang dihadapi, data yang tersedia, maupun target keseluruhan dari penelitian. Meskipun demikian, belum pernah dilakukan kontes berbagai metode di atas untuk suatu kasus pasar, apakah hasilnya searah atau berlawanan.

Untuk kasus pangan di Indonesia, kebanyakan studi menganalisis keterkaitan pasar beras domestik saja, misalnya Alexander and Wyeth (1994), Ismet (2000), Patunru (2004). Ketiga penelitian ini terfokus pada keterkatian pasar beras antar pulau di Indonesia. Basis metodologi yang dipergunakan adalah analisis kointegrasi dan kausalitas Granger. Penelitian mengenai keterkaitan pasar domestik dengan pasar luar negeri masih terbatas. Suryono (1987), menganalisis keterkaitan pasar minyak kelapa sawit mentah (crude palm oil) dengan menggunakan model Armington untuk memformulasi peran minyak sawit mentah Indonesia di pasar internasional. Penelitian yang memasukkan harga internasional di dalam model pasar dalam negeri biasanya memperlakukan harga internasional sebagai variabel eksogen (misalnya Sugiyanto, 2002 untuk kasus minyak kelapa dan kelapa sawit), tanpa menguji terlebih dulu apakah Indonesia sebagai price taker atau price leader. Pengujian hubungan kausalitas antara pasar pangan domestik dengan pasar pangan luar negeri dapat memberikan bukti empiris status pasar pangan Indonesia. Kejelasan status (sebagai lead, lag, berkointegrasi) tersebut memudahkan pelaku ekonomi, termasuk pemerintah, untuk menentukan kebijakan (impor dan ekspor) mengenai pangan.

\section{MASALAH PENELITIAN}

Dari uraian di atas, dapat diamati bahwa fluktuasi harga pangan dunia menimbulkan pertanyaan bagaimana sifat keterkaitan antara pasar pangan domestik dengan pasar internasional. Berapa lama suatu syok di pasar internasional akan berpengaruh terhadap pasar dalam negeri, dan sebaliknya. 


\section{TUJUAN PENELITIAN}

Penelitian ini bertujuan untuk:

1. Menganalisis sifat keterkaitan antara pasar beras domestik dengan pasar internasional

2. Berapa lama syok di beras internasional berpengaruh terhadap pasar domestik

3. Menganalisis keterkaitan pasar beras utama di dalam negeri

Dengan informasi mengenai keterkaitan pasar, apakah pasar domestik mengikuti pasar internasional atau sebaliknya, kapan suatu syok di pasar internasional berpengaruh terhadap pasar domestik, dan bagaimana keterkaitan pasar domestik dapat membantu pelaku ekonomi dan pemerintah untuk menentukan kebijakan ekspor-impor dan hal lain yang berkaitan dengan kebijakan perberasan secara umum (cadangan, operasi pasar).

\section{STUDI PUSTAKA}

\section{Konsep Integrasi Pasar}

Integrasi pasar (keterkaitan antar pasar) dapat dilihat dari dua aspek. Pertama, integrasi vertikal dan integrasi horisontal. Integrasi vertikal adalah keterkaitan industri, sesuai dengan ciri khas industri agribisnis, bahwa suatu produk pertanian yang menjadi output suatu sektor, menjadi input sektor lain yang menghasilkan produk lanjutannya. Integrasi horisontal mencerminkan keterkaitan antar tempat (lokasi). Kedua, integrasi pasar mungkin bisa berupa integrasi antar pasar (spatial market integration), integrasi temporal, integrasi diantara berbagai harga dan integrasi diantara berbagai bentuk produk.

\section{Integrasi antar pasar} mencerminkan pengaruh perubahan harga di suatu pasar terhadap pasar yang lain. Secara teoritis, dalam kondisi persaingan sempurna, apabila dua daerah melakukan perdagangan, harga di daerah importir akan sama dengan harga di daerah eksportir ditambah biaya transport. Dengan demikian, perubahan harga di daerah eksportir akan mendorong perubahan harga di daerah importir dengan arah yang sama dan derajad yang sama. Apabila terjadi demikian, maka kedua pasar (daerah) dikatakan terintegrasi sempurna.

Integrasi pasar bisa berwujud integrasi jangka panjang maupun jangka pendek. Integrasi jangka panjang menunjukkan adanya hubungan dua harga (pasar) yang stabil dalam jangka panjang. Meskipun hubungan harga "keseimbangan" jangka panjang ini terputus dalam jangka pendek, akhirnya keseimbangan akan dicapai kembali. Ini berarti, informasi mengenai adanya surplus atau defisit di suatu daerah ditransmisikan ke pasar yang lain. Integrasi jangka pendek menunjukkan bahwa perubahan harga di satu pasar beberapa waktu kemudian ("dengan segera") menyebabkan perubahan harga di pasar yang lain. Keadaan ini mencerminkan sensitivitas margin (spread) harga di kedua pasar.

\section{Uji Kointegrasi}

Kointegrasi bisa berarti dalam jangka panjang maupun dalam jangka pendek. Perbedaan keduanya adalah: regresi kointegrasi jangka panjang disusun menggunakan variabel dalam level, sedangkan regresi kointegrasi jangka pendek disusun menggunakan variabel beda tingkat pertama (first difference). Untuk bisa menguji kointegrasi, maka series yang dimiliki perlu mempunyai derajad integrasi yang sama. Langkah menuju uji derajad integrasi menggunakan uji stasionaritas. Uji stasionaritas (test for unit roots) antara lain bisa mempergunakan Dickey-Fuller (DF) dan Augmented Dickey-Fuller (ADF).

Tiga persamaan berikut merupakan tiga persamaan yang mencerminkan perilaku: random walk (1) dari harga di dalam negeri (Y), (2) random walk dengan drift, dan (3) random walk dengan drift dan trend. 


$$
\begin{aligned}
& \Delta Y_{t}=(\rho-1) Y_{t-1}+\sum_{k=1}^{p} \delta_{k} \Delta Y_{t-k}+\varepsilon_{t} \\
& \Delta Y_{t}=\alpha+(\rho-1) Y_{t-1}+\sum_{k=1}^{p} \delta_{k} \Delta Y_{t-k}+\varepsilon_{t} \\
& \Delta Y_{t}=\alpha+(\rho-1) Y_{t-1}+\gamma T+\sum_{k=1}^{p} \delta_{k} \Delta Y_{t-k}+\varepsilon_{t}
\end{aligned}
$$

Metode yang sama diperlakukan untuk variabel harga luar negeri (X). Sebelum mengestimasi ADF di atas, perlu ditentukan besarnya nilai $\mathrm{k}$ (variabel lamban, lag). Untuk itu akan diuji mulai dari nilai $\mathrm{k}=1$, dan seterusnya sampai diperoleh SIC yang minimum. Nilai SIC diperoleh dari persamaan (4) berikut ini.

$S I C_{j}=\log \hat{\sigma}_{j}^{2}+\left(k_{j} / n\right) \log n$

dimana $\mathrm{k}$ adalah jumlah parameter, $\mathrm{n}$ jumlah observasi, $\hat{\sigma}_{j}^{2}$ adalah jumlah kuadrat error (residual sum of squares) dibagi $n$, diperoleh dari estimasi model dengan OLS. Selain itu, juga dilakukan pengujian dengan menggunakan $\mathrm{F}$ pada $H_{0}: \delta_{1}=\ldots \ldots \ldots=\delta_{k}=0$ dan $\mathrm{H}_{\mathrm{a}}:$ minimal ada satu $\delta_{k}$ tidak sama dengan nol.

Uji hipotesis stasionaritas adalah: $H_{0}: \rho=1$, terdapat unit root di dalam series (series tidak stasioner)

$H_{0}: \rho<1$, tidak terdapat unit rot di dalam series (series stasioner)

Apabila suatu series tidak stasioner pada level, tetapi stasioner pada beda tingkat pertama (first difference), maka series itu dikatakan berderajad integrasi 1 (I 1). Hal yang sama berlaku untuk derajad integrasi 2, 3 dan seterusnya.

Kointegrasi Jangka Panjang. Uji koitegrasi dilakukan dengan menguji stasionaris residual dari persamaan kointegrasi antara harga di dalam negeri (Y) dan luar negeri (X), setelah keduanya stasioner, sebagai berikut.

$Y_{t}=\beta_{1}+\beta_{2} X_{t}+v_{t}$ dan

$v_{t} \sim \operatorname{iidN}\left(0, \sigma^{2} I_{T}\right)$

Kemudian stasionaritas residual yang mencerminkan kointegrasi diuji dengan uji
Augmented Engle-Granger

(AEG)

persamaan berikut :

$$
\begin{aligned}
& \Delta \hat{v}_{t}=(\rho-1) \hat{v}_{t-1}+\sum_{k=1}^{p} \delta_{k} \Delta \hat{v}_{t-k}+\varepsilon_{t} \\
& \Delta \hat{v}_{t}=\alpha+(\rho-1) \hat{v}_{t-1}+\sum_{k=1}^{p} \delta_{k} \Delta \hat{v}_{t-k}+\varepsilon_{t} \\
& \Delta \hat{v}_{t}=\alpha+(\rho-1) \hat{v}_{t-1}+\gamma T+\sum_{k=1}^{p} \delta_{k} \Delta \hat{v}_{t-k}+\varepsilon_{t}
\end{aligned}
$$

Uji hipotesis stasionaritas adalah: $H_{0}: \rho=1$, terdapat unit root di dalam series (kedua series tidak berkointegrasi) $H_{0}: \rho<1$, tidak terdapat unit root di dalam series (kedua series berkointegrasi)

Kointegrasi Jangka Pendek. Uji kointegrasi jangka pendek dilakukan pada persamaan berikut ini (Bessler and Brandt, 1982).

$$
\begin{aligned}
\Delta Y_{t}= & \mu_{1} \Delta Y_{t-1}+\ldots+\mu_{n} \Delta Y_{t-n}+\gamma_{1} \Delta X_{t-1}+\ldots+\gamma_{n} \Delta X_{t-n} \\
& -\lambda\left(Y_{t-1}-\beta_{1}-\beta_{2} X_{t-1}\right)+\varepsilon_{T}
\end{aligned}
$$

Selanjutnya dilakukan pengujian hipotesis terhadap

$$
H_{0}: \mu_{1}=\ldots \ldots \ldots=\mu_{n}=\gamma_{1}=\ldots=\gamma_{n}=0
$$

dan $H_{1}: \lambda=1$ dengan menggunakan uji $\mathrm{F}$. Apabila nilai $F$ hitung lebih tinggi dari nilai $\mathrm{F}$ kritis, maka hipotesis nol ditolak, maka disimpulkan tidak ada kointegrasi jangka pendek diantara kedua pasar.

\section{Uji Kausalitas Granger}

Kointegrasi memiliki informasi yang terbatas. Aapabila dua series atau lebih berkointegrasi, maka uji kausalitas memberikan informasi apakah suatu series menyebabkan variasi series yang lain (satu arah) atau saling mempengaruhi (dua arah). Berikut ini persamaan umum dengan $\mathrm{k}=1,2,3$, dan 4 dipergunakan untuk menguji kausalitas Granger:

$$
\begin{gathered}
Y_{t}=\mu+\sum_{k=1}^{p} \alpha_{k} Y_{t-k}+\sum_{k=1}^{p} \beta_{k} X_{t-k}+\varepsilon_{t} \\
X_{t}=\mu+\sum_{k=1}^{p} \alpha_{k} X_{t-k}+\sum_{k=1}^{p} \beta_{k} Y_{t-k}+\varepsilon_{t}
\end{gathered}
$$

dimana $\mathrm{Y}$ adalah harga dalam negeri dan $X$ harga luar negeri. Untuk menguji apakah harga luar negeri (X) berpengaruh 
terhadap harga di dalam negeri (Y) maka mula-mula diestimasi persamaan (11) dan kemudian diuji $\mathrm{F}$ hipotesis berikut:

$H_{0}: \beta_{1}=\ldots \ldots \ldots=\beta_{k}=0$, harga luar negeri $(X)$ tidak berpengaruh terhadap harga di dalam negeri (Y)

$\mathrm{H}_{\mathrm{a}}$ : minimal ada satu $\beta_{k}$ tidak sama dengan nol, harga luar negeri (X) berpengaruh terhadap harga di dalam negeri (Y).

Sebaliknya, untuk menguji apakah harga dalam negeri (Y) berpengaruh terhadap harga di luar negeri $(\mathrm{X})$ maka mula-mula diestimasi persamaan (11) dan kemudian diuji $\mathrm{F}$ hipotesis berikut:

$H_{0}: \beta_{1}=\ldots \ldots \ldots=\beta_{k}=0$, harga dalam negeri (Y) tidak berpengaruh terhadap harga di luar negeri $(\mathrm{X})$

$\mathrm{H}_{\mathrm{a}}$ : minimal ada satu $\beta_{k}$ tidak sama dengan nol, harga dalam negeri berpengaruh terhadap harga di luar negeri.

\section{Fungsi Impulse Response}

Uji kausalitas memberikan informasi mengenai arah kusalitas. Berapa lama/cepat kenaikan harga di luar negeri berpengaruh terhadap harga di dalam negeri, dan sebaliknya dideteksi dengan fungsi impuls (impulse response function). Fungsi ini menggambarkan rute (path) yang ditempuh oleh suatu penyimpangan dari keseimbangan atas suatu variabel (misalnya harga) menuju titik keseimbangannya semula atau tidak. Ilustrasinya sebagai berikut (lihat misalnya Hamilton, 1994): misalkan perkembangan harga jagung dalam negeri dna luar negeri (X) bergerak secara autoregresif (Vector Auto Regressive, VAR). Maka dari waktu ke waktu :

$$
X_{t}=\mu+\Delta_{1} X_{t-1}+\Delta_{2} X_{t-2}+v_{t}
$$

dalam kondisi stabilitas, maka perkembangan harga (X) menjauh dari keseimbangan $(\bar{X})$ sesuai dengan persamaan berikut:

$$
X_{t}=\bar{X}+v_{t}+\Delta v_{t-1}+\Delta_{2} v_{t-2}+\ldots
$$

Koefesien pada $\Delta$ menunjukkan multiplier dari persamaan. Kita dapat mengidentifikasi dampak perubahan yang terjadi pada $\mathrm{v}_{\mathrm{t}}$ terhadap $\mathrm{X}_{\mathrm{t}}$. Misalkan terdapat sekali syok berupa perubahan harga di luar negeri (atau perubahan harga di dalam negeri) sebesar $d_{t}$. Dibandingkan dengan posisi keseimbangannya, nilai $\mathrm{X}$ pada saat $\mathrm{t}$ menjadi:

$$
X_{t}-\bar{X}=d v_{t}=\phi_{t}(0) d v_{t}
$$

Satu periode kemudian menjadi

$$
X_{t+1}-\bar{X}=\Delta d v_{t}=\phi_{t}(1) d v_{t}
$$

Dua periode kemudian menjadi:

$$
X_{t+1}-\bar{X}=\Delta^{2} d v_{t}=\phi_{t}(2) d v_{t}
$$

Demikian seterusnya. Fungsi $\phi_{t}(i)$

memberikan karakteristik impulse response $\mathrm{X}_{\mathrm{t}}$ karena perubahan syok berupa $\mathrm{dv}_{\mathrm{t}}$. Grafik dari fungsi tersebut mencerminkan berapa lama syok menyebabkan perubahan $\mathrm{X}$ dan kapan akan kembali ke nilai keseimbangan, baik syok yang jagungal dari harga jagung luar negeri pengaruhnya terhadap harga di dalam negeri dan sebaliknya.

Vector Error Correction Model, VECM, merupakan model VAR yang terestriksi kointegrasi. VECM dapat menjawab tujuan penelitian yaitu, untuk melihat adanya kausalitas, kointegrasi serta pengaruh syok pasar beras internasional ke pasar beras domestic. Syarat agar data dapat dianlisis dengan menggunakan VECM adalah data tersebut stasioner pada derajat 1 dan terkointegrasi.

\section{DATA}

Penelitian ini akan menggunakan data sekunder. Data yang digunakan dalam penelitian ini merupakan data bulanan dari tahun 2000 hingga tahun 2010. Untuk harga beras Indonesia diperoleh dari Bulog, yaitu harga beras medium per $\mathrm{kg}$. Untuk harga beras dunia, diperoleh dari website FAO, berupa harga beras Thailand A1 super per US\$/ton. 


\section{HASIL ANALISIS DATA}

\section{Analisis}

Penelitian ini diharapkan memperoleh hasil sebagai berikut: pertama, sebeberapa besar keterkaitan antara pasar beras dalam negeri dengan di luar negeri: adakah hubungan jangka panjang, jangka pendek atau keduanya. Kedua, status hubungan antara pasar beras di dalam negeri dan di luar negeri: apakah sebagai lead atau lag. Ketiga, seberapa cepat syok dari luar negeri akan berpengaruh terhadap pasar dalam negeri. Dari hasil analisis tersebut diharapkan pelaku ekonomi daat memutuskan mengenai kebijakan harga (pricing) di pasar ekspor/impor, keputusan ekspor/impor maupun dalam penentuan stok, dan penyelesaian hambatan pemasaran agar pemasaran lebih efisien.

Pasar beras domestic vs luar negeri. Dua variabel yang digunakan dalam penelitian ini adalah Ina dan World. Variabel Ina merupakan harga beras medium di Indonesia sedangkan variabel World merupakan harga beras dunia. Hasil uji stasioneritas dengan menggunakan metode Phillips-Perron menunjukkan bahwa kedua variabel tersebut tidak stasioner pada level, namun pada derajat 1 , kedua variabel stasioner (Tabel 1).

Tabel 1. Uji Stasioneritas

\begin{tabular}{|c|l|r|r|r|}
\hline \multicolumn{2}{|c|}{} & \multicolumn{1}{|c|}{ None } & \multicolumn{1}{c|}{ Intersep } & \multicolumn{2}{|c|}{ Intersep dan trend } \\
\hline \multirow{2}{*}{ INA } & Level & 1 & 1 & 0.9921 \\
\cline { 2 - 5 } & Derajat 1 & 0 & 0 & 0 \\
\hline \multirow{2}{*}{ World } & Level & 0.6039 & 0.4429 & 0.1025 \\
\cline { 2 - 5 } & Derajat 1 & 0 & 0 & 0 \\
\hline
\end{tabular}

Sumber: diolah

Kedua variabel telah stasioner pada derajat 1 , ada tiga kemungkinan model yang dapat digunakan, yaitu VAR in difference, VECM, ataupun SVAR. Sebelum menentukan akan menggunakan model yang mana, tahap selanjutnya adalah menentukan lag yang akan digunakan dalam VAR. Dengan menggunakan beberapa criteria, nantinya akan dipilih model VAR dengan criteria terbaik berdasarkan nilai AIC dan SIC.

Penelitian ini mencoba untuk mengunakan dua model estimasi VAR, model pertama dengan menggunakan lag 4 (model 1) dan model kedua menggunakan lag 2 (model 2) untuk melihat lag manakah yang lebih baik untuk digunakan. Dari hasil estimasi kedua model, tidak lantas menunjukkan hasil yang signifikan karena kemungkinan adanya multikolinearitas (Gudjarati, 2003). Namun demikian, model VAR dapat dilihat signifikansinya dengan mempertimbangkan $F$ statistic. Nilai F statustik model 1 (5.777121) lebih kecil dibandingkan VAR dengan model 2 (11.42523). Nilai $F$ statistic sendiri menunjukkan signifikansi model dan kedua model tersebut memiliki nilai $\mathrm{F}$ yang signifikan dengan $\alpha=5 \%$. Nilai Rsquared kedua model tersebut sangat kecil yaitu dibawah $25 \%$ yang menunjukkan bahwa sesungguhnya variabel dalam model tersebut belum cukup untuk menjelaskan fenomena yang terjadi. 
Tabel 2. Estimasi VAR

\begin{tabular}{|c|c|c|c|c|c|}
\hline & \multicolumn{2}{|c|}{ Model 1 (4 lag) } & & \multicolumn{2}{|c|}{ Model 2 (2 lag) } \\
\hline & D(INA) & D(WORLD) & & D(INA) & D(WORLD) \\
\hline \multirow[t]{3}{*}{$\mathrm{D}(\operatorname{INA}(-1))$} & 0.577954 & $-1.24 \mathrm{E}-05$ & \multirow[t]{3}{*}{$\overline{\mathrm{D}(\mathrm{INA}(-1))}$} & 0.578183 & $-1.30 \mathrm{E}-05$ \\
\hline & -0.0989 & $-2.40 \mathrm{E}-05$ & & -0.09008 & $-2.20 \mathrm{E}-05$ \\
\hline & [ 5.8438] & {$[-0.51046]$} & & [ 6.4187] & {$[-0.58921]$} \\
\hline \multirow[t]{3}{*}{$\mathrm{D}(\mathrm{INA}(-2))$} & -0.281296 & $1.16 \mathrm{E}-05$ & \multirow[t]{3}{*}{$\mathrm{D}(\operatorname{INA}(-2))$} & -0.33129 & $2.73 \mathrm{E}-05$ \\
\hline & -0.11188 & $-2.70 \mathrm{E}-05$ & & -0.0891 & $-2.20 \mathrm{E}-05$ \\
\hline & {$[-2.5142]$} & [ 0.42109] & & {$[-3.7182]$} & [ 1.24731$]$ \\
\hline \multirow[t]{3}{*}{$\mathrm{D}(\operatorname{INA}(-3))$} & -0.09083 & $2.53 \mathrm{E}-05$ & \multirow[t]{3}{*}{$\mathrm{D}(\mathrm{WORLD}(-1))$} & 674.9629 & 0.741928 \\
\hline & -0.11037 & $-2.70 \mathrm{E}-05$ & & -346.621 & -0.08517 \\
\hline & {$[-0.8229]$} & {$[0.93375]$} & & [ 1.9473] & [ 8.71095] \\
\hline \multirow[t]{3}{*}{$\mathrm{D}(\mathrm{INA}(-4))$} & 0.082582 & $-2.78 \mathrm{E}-05$ & \multirow[t]{3}{*}{$\mathrm{D}(\mathrm{WORLD}(-2))$} & -468.5244 & -0.30731 \\
\hline & -0.09605 & $-2.40 \mathrm{E}-05$ & & -350.093 & -0.08603 \\
\hline & [ 0.8598$]$ & {$[-1.17875]$} & & {$[-1.3383]$} & {$[-3.57233]$} \\
\hline \multirow[t]{4}{*}{ D(WRLD(-1)) } & 628.5672 & 0.754558 & \multirow[t]{3}{*}{$\mathrm{C}$} & 33.30569 & 0.000627 \\
\hline & -373.184 & -0.09161 & & -9.32691 & -0.00229 \\
\hline & [ 1.6843$]$ & [ 8.23646] & & [3.5709] & {$[0.27345]$} \\
\hline & & & R-squared & 0.269303 & 0.392 \\
\hline \multirow[t]{3}{*}{ D(WRLD(-2)) } & -303.4143 & -0.348602 & \multirow[t]{14}{*}{ F-statistic } & 11.42523 & 19.98687 \\
\hline & -473.569 & -0.11626 & & & \\
\hline & {$[-0.6407]$} & {$[-2.99860]$} & & & \\
\hline $\mathrm{D}(\mathrm{WRLD}(-3))$ & -345.6905 & 0.088878 & & & \\
\hline & -475.916 & -0.11683 & & & \\
\hline & {$[-0.7263]$} & {$[0.76074]$} & & & \\
\hline \multirow[t]{3}{*}{ D(WRLD(-4)) } & 281.3843 & -0.078673 & & & \\
\hline & -383.735 & -0.0942 & & & \\
\hline & [ 0.73328$]$ & {$[-0.83515]$} & & & \\
\hline \multirow[t]{3}{*}{$\mathrm{C}$} & 31.34443 & 0.001411 & & & \\
\hline & -10.4685 & -0.00257 & & & \\
\hline & [ 2.99417] & [ 0.54904$]$ & & & \\
\hline R-squared & 0.281438 & 0.403216 & & & \\
\hline F-statistic & 5.777121 & 9.965796 & & & \\
\hline
\end{tabular}

Sumber: Diolah

Menggunakan model dengan banyak lag sangatlah tidak efisien, untuk itu perlu dipertimbangkan menggunakan model dengan lag yang lebih sedikit. Salah satu cara untuk menentukan lag berapa yang akan digunakan dalam model, penggunaan criteria seperti Akaike dan Schwarz sangat bermanfaat. Peneliti selanjutnya memilih menggunakan model dengan lag yang terpilih oleh criteria tersebut.
Dari kedua model, dengan menggunakan uji Lag Length Criteria, lag 2 merupakan lag yang terpilih oleh AIC dan SIC. Sehingga model penelitian ini secara konsisten akan menggunakan lag 2 (Tabel 3). Untuk memastikan stabilitas model dengan menggunakan lag 2, uji stabilitas dengan melihat akar unit dilakukan, dan hasilnya menunjukkan bahwa model VAR dengan lag 2 stabil. 
Tabel 3. Kriteria Panjangnya Lag

\begin{tabular}{|c|c|c|c|c|c|c|}
\hline \multicolumn{7}{|c|}{ Model 1} \\
\hline Lag & $\log \mathrm{L}$ & LR & FPE & AIC & $\mathrm{SC}$ & HQ \\
\hline 0 & -503.91 & $\overline{\mathrm{NA}}$ & 11.9914 & 8.159943 & 8.205432 & 8.178422 \\
\hline 1 & -467.53 & 71.00997 & 7.112579 & 7.6376 & 7.774065 & 7.693036 \\
\hline 2 & -452.93 & $28.0212 *$ & $5.995306^{*}$ & 7.46664* & $7.69408^{*}$ & $7.559036^{*}$ \\
\hline 3 & -452.66 & 0.513807 & 6.367802 & 7.526768 & 7.845187 & 7.656117 \\
\hline 4 & -451.12 & 2.845126 & 6.627988 & 7.566544 & 7.97594 & 7.73285 \\
\hline 5 & -449.07 & 3.747404 & 6.841988 & 7.597897 & 8.09827 & 7.80116 \\
\hline 6 & -445.17 & 6.965588 & 6.858254 & 7.59966 & 8.19101 & 7.83988 \\
\hline 7 & -444.17 & 1.768871 & 7.20356 & 7.647948 & 8.330275 & 7.925125 \\
\hline \multicolumn{7}{|c|}{ Model 2} \\
\hline Lag & $\log L$ & LR & FPE & AIC & $\mathrm{SC}$ & HQ \\
\hline 0 & -503.91 & NA & 11.9914 & 8.159943 & 8.205432 & 8.178422 \\
\hline 1 & -467.53 & 71.00997 & 7.112579 & 7.6376 & 7.774065 & 7.693036 \\
\hline 2 & -452.93 & $28.02126^{*}$ & $5.995306^{*}$ & 7.466644* & 7.694086* & $7.559036^{*}$ \\
\hline 3 & -452.66 & 0.513807 & 6.367802 & 7.526768 & 7.845187 & 7.656117 \\
\hline 4 & -451.12 & 2.845126 & 6.627988 & 7.566544 & 7.97594 & 7.73285 \\
\hline 5 & -449.07 & 3.747404 & 6.841988 & 7.597897 & 8.09827 & 7.80116 \\
\hline 6 & -445.17 & 6.965588 & 6.858254 & 7.59966 & 8.19101 & 7.83988 \\
\hline 7 & -444.173 & 1.768871 & 7.20356 & 7.647948 & 8.330275 & 7.925125 \\
\hline
\end{tabular}

Sumber: Diolah

\section{Gambar 1. Uji stabilitas dengan grafik AR} roots

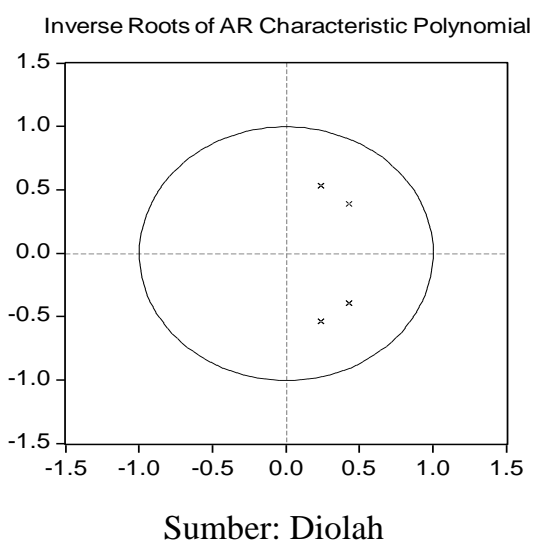

Salah satu syarat VECM adalah variabel tersebut terkointegrasi. Untuk menjawab salah satu tujuan penelitian, tentang adanya hubungan jangka panjang harga beras domestic dengan dunia, Johansen test cointegration digunakan. Dari hasil test didapat bahwa pada $\alpha \quad(5 \%$ dan $1 \%)$, diindikasikan ada dua kointegrasi. Karena terjadi kointegrasi, maka model VAR yang akan digunakan adalah VECM.

Tabel 4. Uji Kointegrasi

Unrestricted Cointegration Rank Test

\begin{tabular}{ccccc}
\hline \hline $\begin{array}{c}\text { Hypothesized } \\
\text { No. of CE(s) }\end{array}$ & Eigenvalue & $\begin{array}{c}\text { Trace } \\
\text { Statistic }\end{array}$ & $\begin{array}{c}\text { 5 Percent } \\
\text { Critical Value }\end{array}$ & $\begin{array}{c}\text { 1 Percent } \\
\text { Critical Value }\end{array}$ \\
\hline \hline None $* *$ & 0.247838 & 67.01215 & 15.41 & 20.04 \\
At most 1 $* *$ & 0.212372 & 30.55729 & 3.76 & 6.65 \\
\hline \hline
\end{tabular}

$*(* *)$ denotes rejection of the hypothesis at the $5 \%(1 \%)$ level

Trace test indicates 2 cointegrating equation(s) at both $5 \%$ and $1 \%$ levels

\begin{tabular}{ccccc}
\hline \hline $\begin{array}{c}\text { Hypothesized } \\
\text { No. of CE(s) }\end{array}$ & Eigenvalue & $\begin{array}{c}\text { Max-Eigen } \\
\text { Statistic }\end{array}$ & $\begin{array}{c}\text { 5 Percent } \\
\text { Critical Value }\end{array}$ & $\begin{array}{c}\text { 1 Percent } \\
\text { Critical Value }\end{array}$ \\
\hline \hline None $* *$ & 0.247838 & 36.45486 & 14.07 & 18.63 \\
At most 1 $* *$ & 0.212372 & 30.55729 & 3.76 & 6.65 \\
\hline \hline
\end{tabular}

$*(* *)$ denotes rejection of the hypothesis at the 5\%(1\%) level

Max-eigenvalue test indicates 2 cointegrating equation(s) at both 5\% and $1 \%$ levels Sumber: Diolah 
Tabel 4 menunjukkan hasil uji kointegrasi. Dari hasil uji, pada $\alpha$ (5\% dan $1 \%$ ), kedua variabel memiliki setidaknya dua kointegrasi. Dalam jangka panjang, kedua variabel akan terkointegrasi. Dengan variabel yang terkointegrasi dalam jangka panjang, estimasi VECM dapat dilakukan. Tabel 5 menunjukkan hasil estimasi VECM. Dengan memperhatikan t-statistic $\alpha$ (5\%), variabel Ina mempengaruhi secara signifikan variabel
Ina pada lag 2. Variabel Ina juga berpengaruh signifikan pada variabel World pada lag 2, sedangkan variabel World berpengaruh secara signifikan pada lag 1. Nilai $F$ statistic cukup tinggi yang menunjukkan bahwa secara kolektif, variabel model VECM dalam penelitian ini signifikan. Nilai R-squared yang rendah menunjukkan bahwa masih ada variabel lain yang mempengaruhi model.

Tabel 5. Hasil Estimasi VECM

\begin{tabular}{|c|c|c|}
\hline Cointegrating Eq: & CointEq1 & \\
\hline $\mathrm{D}(\mathrm{INA}(-1))$ & 1.000000 & \\
\hline $\mathrm{D}(\mathrm{WORLD}(-1))$ & $\begin{array}{r}-525.1334 \\
(497.776) \\
{[-1.05496]}\end{array}$ & \\
\hline $\mathrm{C}$ & -38.93751 & \\
\hline Error Correction: & $\mathrm{D}(\mathrm{INA}, 2)$ & $\mathrm{D}(\mathrm{WORLD}, 2)$ \\
\hline CointEq1 & $\begin{array}{r}-0.768857 \\
(0.12251) \\
{[-6.27612]}\end{array}$ & $\begin{array}{r}3.93 \mathrm{E}-05 \\
(3.4 \mathrm{E}-05) \\
{[1.16426]}\end{array}$ \\
\hline $\mathrm{D}(\mathrm{INA}(-1), 2)$ & $\begin{array}{r}0.343865 \\
(0.10176) \\
{[3.37916]}\end{array}$ & $\begin{array}{r}-3.61 \mathrm{E}-05 \\
(2.8 \mathrm{E}-05) \\
{[-1.28736]}\end{array}$ \\
\hline $\mathrm{D}(\mathrm{INA}(-2), 2)$ & $\begin{array}{r}0.032785 \\
(0.09470) \\
{[0.34619]}\end{array}$ & $\begin{array}{r}-1.89 E-05 \\
(2.6 E-05) \\
{[-0.72482]}\end{array}$ \\
\hline $\mathrm{D}(\mathrm{WORLD}(-1), 2)$ & $\begin{array}{r}384.5180 \\
(315.033) \\
{[1.22056]}\end{array}$ & $\begin{array}{r}0.042812 \\
(0.08681) \\
{[0.49319]}\end{array}$ \\
\hline D(WORLD(-2),2) & $\begin{array}{r}8.740905 \\
(318.107) \\
{[0.02748]}\end{array}$ & $\begin{array}{r}-0.311311 \\
(0.08765) \\
{[-3.55163]}\end{array}$ \\
\hline C & $\begin{array}{r}3.088506 \\
(8.58349) \\
{[0.35982]} \\
\end{array}$ & $\begin{array}{r}6.78 \mathrm{E}-05 \\
(0.00237) \\
{[0.02865]} \\
\end{array}$ \\
\hline $\begin{array}{l}\text { R-squared } \\
\text { F-statistic } \\
\text { Sumber: Diolah }\end{array}$ & $\begin{array}{l}0.349569 \\
13.11356\end{array}$ & $\begin{array}{l}0.124847 \\
3.480844\end{array}$ \\
\hline
\end{tabular}


Model VAR memang melihat hubungan satu variabel dengan variabel lain (hubungan kausalitas). Dengan menggunakan Granger Causality Test, deteksi hubungan kausalitas antara variabel Ina dan World dapat ditunjukkan. Tabel 6 menunjukkan hasil Uji Granger Causality. Dari hasil uji, harga beras domestic secara signifikan mempengaruhi harga beras dunia, dan tidak sebaliknya.

Tabel 6. Uji Kausalitas Granger

\begin{tabular}{|c|c|c|c|}
\hline Null Hypothesis: & Obs & F-Statistic & Prob. \\
\hline Ina does not Granger Cause World & 17 & 6.96427 & 0.0194 \\
\hline Ina does not Granger Cause World & & 0.00579 & 0.9404 \\
\hline
\end{tabular}

Sumber: Diolah

Dari hasil analisis dengan menggunakan model VECM, nampak bahwa harga beras domestic dan harga beras dunia memiliki hubungan kointegrasi dan harga beras dometik mempengaruhi harga beras dunia. Dilihat dengan menggunakan Impulse Response Function (IRF), yang menggambarkan respon suatu variabel pada saat ini dan masa depan akibat perubahan atau shock suatu variabel tertentu, respon harga beras dunia lebih lambat untuk stabil dibandingkan dengan harga beras domestic, walaupun harga beras domestic lebih fluktuatif jika terjadi shock.

Gambar 2. Kurva Impulse Response

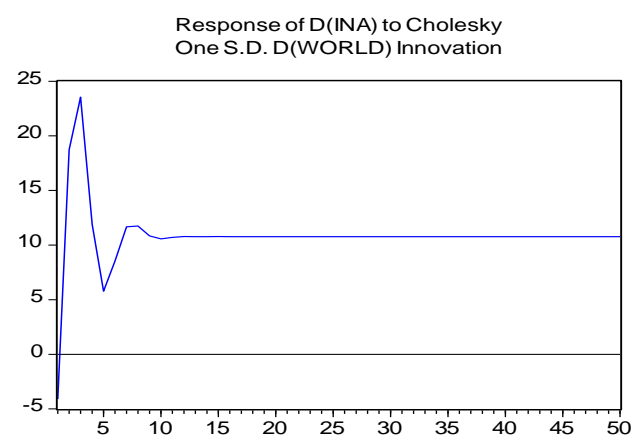

Sumber: Diolah

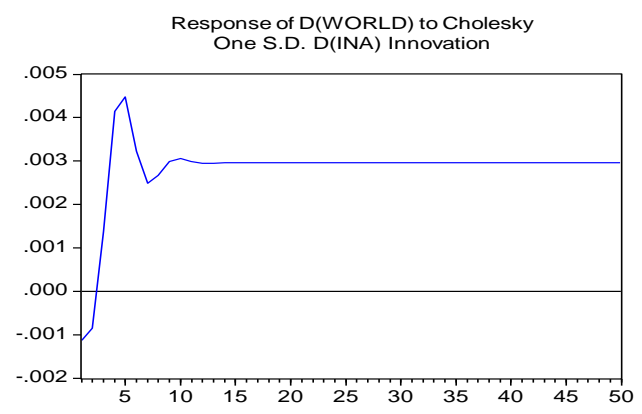

Sumber: Diolah

\section{Pembahasan}

Perkembangan harga beras di dalam negeri dan di luar negeri dilaporkan dalam gambar 2. Terlihat keeratan hubungan antara harga beras di dalam negeri dengan harga beras di luar negeri. Kedua pasar, dalam negeri dan luar negeri, nampaknya saling berkaitan. Mengikuti hukum pasar, perbedaan harga akan mendorong aliran beras dari pasar yang harganya rendah menuju psar yang harganya tinggi, proses arbitrase. Aliran beras tersobot akan mengakibatkan perubahan penawaran sehingga mempengaruhi harga keseimbangan. Keterkaitan pasar beras dalam negeri dan luar negeri seperti ini mengindikasikan adanya kointegrasi diantara kedua pasar. 


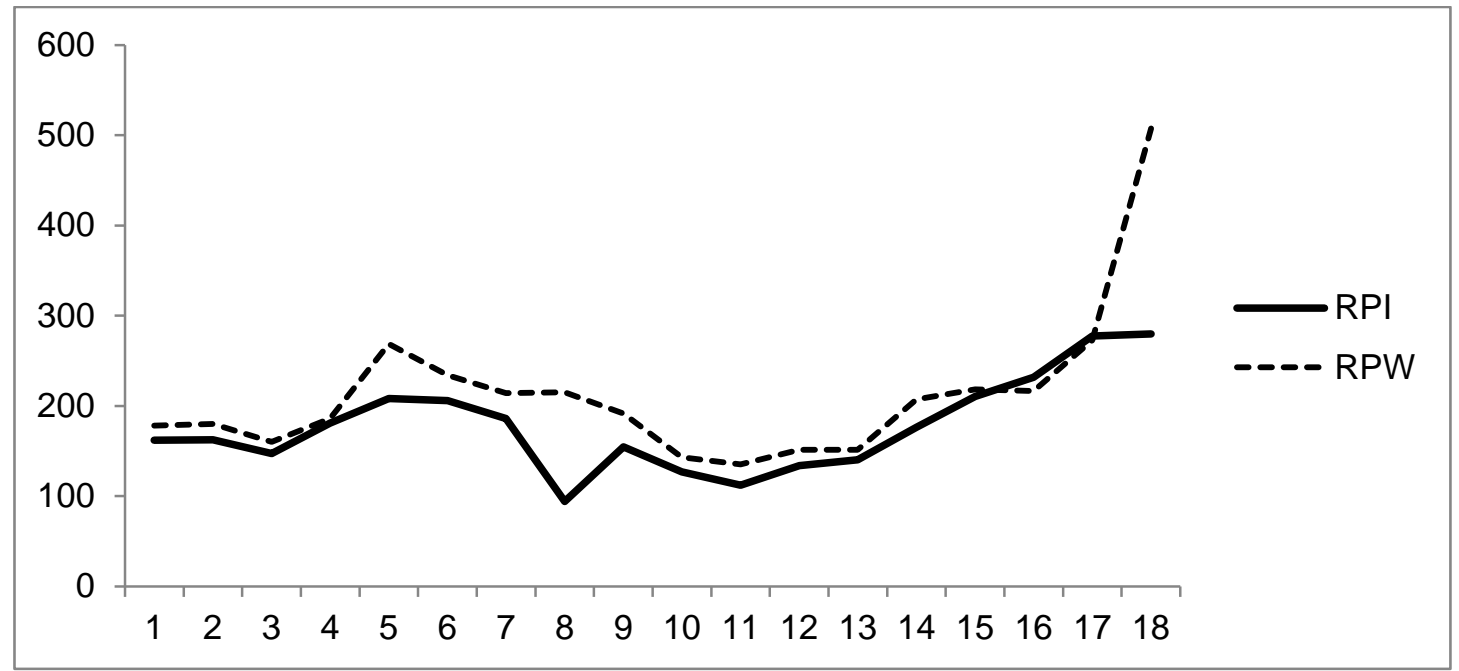

Gambar 3. Keterkaitan Harga Beras Dalam Negeri (RPI) dengan harga Beras Luar Negeri (RPW), 2000-2010

Keterkaitan harga di kedua pasar dikaji secara statistic dalam dua aspek: apakah terjadi keseimbangan jangka panjang (kointegrasi) dan sebab-akibat (kausalitas). Dari hasil uji kointegrasi mengkonformasi bahwa hubungan antara kedua pasar berada dalam keseimbangan. Setiap ada penyimpangan yang mengarah keluar dari keseimbangan, maka mekanisme pasar akan membawa ke titik keseimbangan lagi. Proses arbitrase di atas terjadi secara otomatis, tanpa adanya campur tangan pemerintah atau pihak lain.

Arah hubungan atau pengaruh dari kedua pasar, sebagaimana hasil uji kausalitas Granger, menunjukkan bahwa harga beras domestik secara signifikan mempengaruhi harga beras dunia, dan tidak sebaliknya. Hal ini menunjukkan bahwa pasar beras di Indonesia menjadi leader terhadap pasar beras di luar negeri. Potensi konsumsi yang besar dan wilayah yang luas mungkin menjadi penyebab mengapa pasar Indonesia menjadi leader. Setiap gejolak pasar yang terjadi di dalam negeri akan direspon oleh pelaku pasar di luar negeri.

Meskipun demikian, reaksi terhadap perubahan harga di kedua pasar tidak seragam. Pasar di dalam negeri lebih reaktif daripada pasar di luar negeri.
Mengingat bahwa pasar di dalam negeri terdiri dari konsumen dalam jumlah yang banyak dan wilayah yang luas, maka tidak heran bila menjadi lebih reaktif. Sementara itu, pasar di luar negeri relative tersebar dan masing-masing Negara biasanya mempunyai stok untuk berjaga-jaga, sehingga menjadi mekanisme meredam gejolak.

Impulse Response Function (IRF), yang menggambarkan respon suatu variabel pada saat ini dan masa depan akibat perubahan atau shock suatu variabel tertentu, respon harga beras dunia lebih lambat untuk stabil dibandingkan dengan harga beras domestic, walaupun harga beras domestic lebih fluktuatif jika terjadi shock.

Apabila ada shock, pasar di Indonesia lebih cepat meredam shock sementara di pasar luar negeri lebih lamban. Hal ini bisa dipahami mengingat penting dan rentannya pasar beras di dalam negeri sehingga intervensi pemerintah sangat diperlukan dan sering dilakukan. Meskipun demikian, kedua pasar menuju ke kestabilan dalam waktu yang sama, sekitar 12 bulan. Proses arbitrasi menuju pada harga keseimbangan di kedua pasar terjadi bersama-sama.

Tabel 7. Hasil Uji Kausalitas Granger antar Pasar di Dalam Negeri 


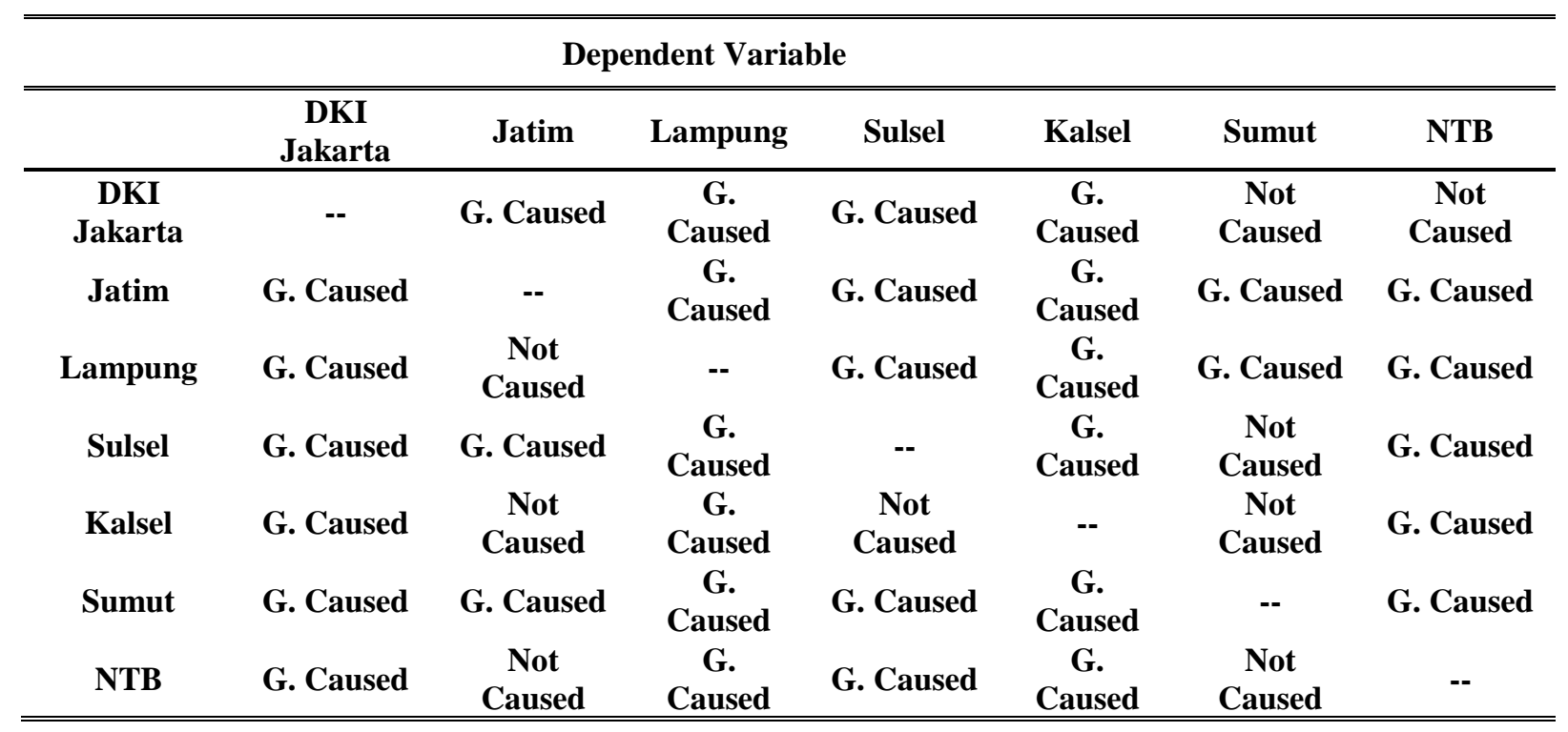

Pasar di dalam negeri menunjukkan keterkaitan, meskipun tidak selamanya simetri (dua arah). Pasar domestic, dari sisi produsen, masih terkonsentrasi di Jawa Timur, Sulawesi Selatan dan Sumatera Selatan. Kekuatan produsen yang baru adalah Lampung, NTB, dan Kalimantan Selatan. Kekuatan konsumen besar ada di DKI Jakarta yang menjadi pusatnya, Jawa Timur, dan Sumatera Utara. Sumatera utara ini kemungkinan karena dekat dengan Singapore sehingga menjadi alternatif hub beras internasional yang masuk daerah Sumatera bagian utara.

Pasar beras di Jatim dan Sumut merupakan pasar yang memiliki kausalitas terhadap semua pasar beras di daerah lain. Apa yang terjadi di Jawa Timur dan Sumatera akan ditransmisikan ke semua daerah. Sebaliknya, pasar beras DKI Jakarta dipengaruhi oleh semua fluktuasi di daerah lain. Keterkaitan berbagai pasar di dalam negeri tersebut berpengaruh terhadap fluktuasi harga dan berapa lama suatu shock akan diredam. Semakin tinggi tingkat hubungan kedua pasar, maka Dengan demikian, Jawa Timur, Sumatera Utara, Sumatera Selatan, dan Sulawesi Selatan merupakan pasar eceran beras medium utama di Indonesia. Ini terlihat dari pergerakan harga eceran beras medium di keempat provinsi tersebut memiliki pengaruh di beberapa provinsi proses arbitrase semakin cepat. Oleh karena itu, hasil ini mendukung pembahasan di atas bahwa pasar beras domestic lebih cepat menuju keseimbangan, meskipun lebih berfluktuatif.

Berdasarkan uji kausalitas harga eceran beras medium untuk identifikasi keterkaitan antar-pasar di tujuh provinsi (DKI Jakarta, Jawa Timur, Sumatera Selatan, Sulawesi Selatan, Kalimantan Selatan, Sumatera Utara, dan NTB) terlihat bahwa Provinsi Sumatera Selatan, Sumatera Utara, Sulawesi Selatan, dan Provinsi Jawa Timur memiliki pengaruh terhadap pasar beras di provinsi lain. Ini berarti bahwa pergerakan harga eceran beras medium masing-masing provinsi tersebut mempengaruhi pergerakan harga eceran beras medium di keenam provinsi lain sedangkan Provinsi DKI Jakarta, Sulawesi Selatan, NTB, dan Kalimantan Selatan menjadi provinsi dimana pergerakan harga eceran berasnya dipengaruhi oleh harga eceran beras medium di provinsi lain.

lainnya. Dilihat dari kepentingan spasialnya, keempat pasar ini memegang peranan penting untuk komoditas beras medium dimana Provinsi Sumatera Utara dan Provinsi Sumatera Selatan untuk Indonesia bagian barat, Jawa Timur untuk Indonesia bagian tengah, serta Sulawesi 
Selatan untuk Indonesia bagian timur. Sementara itu, DKI Jakarta, Kalimantan Selatan, dan NTB merupakan pasar dimana harga eceran beras mediumnya dipengaruhi oleh pasar di provinsi lain.

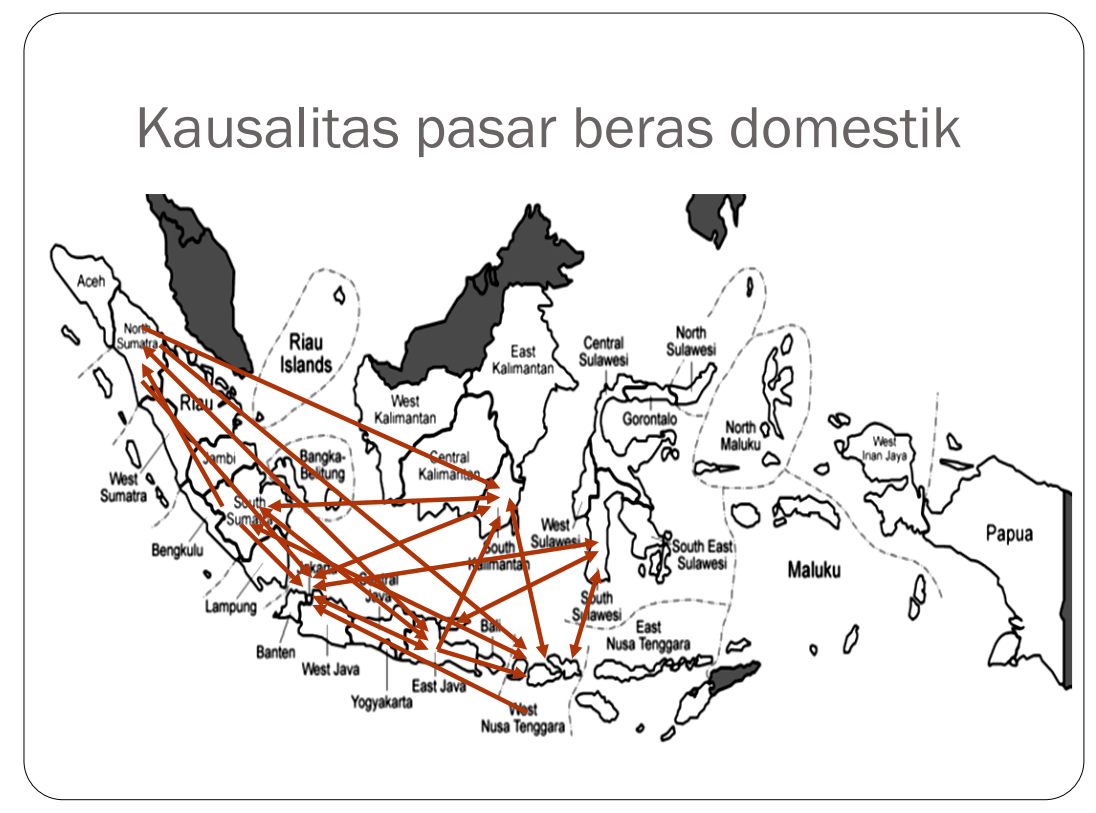

Dari gambar terlihat bahwa pasar domestic terfokus di Indonesia bagian barat saja. Indonesia bagian timur, yang secara geografis luas, terdiri atas pulaupulau yang perlu dibuatkan mekanisme saling ketergantungan agar terbangun integrasi dan keterkaitan pasar. Saling ketergantungan membuat mekanisme pasar bekerja. Hal ini memudahkan di dalam pengelolaan stok beras.

\section{KESIMPULAN}

Penelitian ini bertujuan untuk: 1) menganalisis sifat keterkaitan antara pasar beras domestik dengan pasar internasional; 2) mengestimasi berapa lama syok di beras internasional berpengaruh terhadap pasar domestik, dan 3) menganalisis keterkaitan pasar bers utama di dalam negeri. Dari hasil analisis dan pembahasan diperoleh kesimpulan sebagai berikut.

Pasar beras adalah pasar yang sangat sensitif terhadap perubahan (contestable?) Pasar beras terintegrasi, baik di dalam negeri maupun dengan luar negeri, sehingga setiap fluktuasi di kedua pasar akan saling berpengaruh. Integrasi tersebut juga membawa hikmah bahwa mekanisme pasar berjalan dengan baik. Pasar di dalam negeri berpengaruh terhadap pasar beras internasional. Sebagai Negara dengan konsumen yang besar, ini berarti kekuatan konsumen menjadi perhitungan pasar internasional. Pembelian oleh Indonesia mestinya dilakukan dengan kekautan bargaining yang cukup mengingat kemampuannya sebagai konsumen besar. Namun harus juga diingat bahwa pasar beras internasional adalah pasar yang tipis, sehingga gejolak konsumsi/impor sedikit akan besar pengaruhnya. Justru dari segi ini Indonesia bisa lemah posisi tawarnya di pasar internasional.

Di pasar dalam negeri, mekanisme transmisi harga antar pasar kelihatan bekerja dengan baik. Namun harus juga diingat bahwa bekerjanya mekanisme tersebut juga dipengaruhi oleh intervensi pemerintah (Bulog, operasi pasar, raskin dsb). Dengan demikian, menginterpretasikan bekerjanya mekanisme transmisi harga diikuti dengan 
pengertian bahwa banyak informasi telah disediakan pemerintah untk mempengaruhi mekanisme tersebut, bukan lepas sepenuhnya kepada mekanisme pasar. Pasar beras memang unik, mengingat besarnya kepentingan pemerintah dan jumlah pemain yang terlibat (banyak konsumen dan petani). Oleh karena itu, mekanisme transmisi tersebut hendaknya menjadi signal bagaimana pasar mendorong aliran beras dari daerah surplus ke daerah minus (deficit). Masalah timing, kapan, waktu aliran terjadi juga menjadi masalah. Namun masalah waktu belum secara spesifik dianalisis.

Kesimpulan mengenai bekerjanya pasar beras Indonesia, baik domestik maupun dengan luar negeri mempunyai konsekuensi bahwa manajemen stok dan distribusi di dalam negeri krusial untuk kestabilan harga (isolasi pengaruh luar negeri). Meskipun di dalam negeri pasar terintegrasi, namun jaminan aliran beras antar pasar harus ada agar gejolak harga beras tidak berkepanjangan.

\section{DAFTAR PUSTAKA}

Alexander C and Wyeth J (1994), Cointegration and market integration: an application to Indonesian rice market, Journal of Development Studies, 30:303-328

Ardeni, P.G. 1989, Does the Law of One Price hold for commodity prices? American Journal of Agricultural Economics, 71: 303-328

Baffes, J 1991, Some further evidence of The Law of One Price, American Journal of Agricultural Economics, 4:21-37

Baulch, B. (1997). "Testing for Food Market Integration Revisited." Journal of Development Studies 33(4): 512-34.

Dickey, D. \& Fuller, W. 1979. Distribution of the Estimators for autoregressive time series with a unit root,
Journal of the American Statistical Association, 74:427-431.

Engle, R.F. \& Granger, C.W.J. 1987. Cointegration and error correction: representation, estimation and testing, Econometrica, 55:251-276.

Gardner B and K Brooks, 1994; Food price and market integration in Russia:1992- 1993, American Journal of Agricultural Economics, 76:641-666

Granger, C.W.J. 1988. Some recent developments in the concept of causality." Journal of Econometrics, 39:199-211.

Hamilton, J.D. 1994. Time Series Analysis. Princeton: Princeton University Press.

Ismet M (2000), Analisis Efisiensi pasar beras di Indonesia, Jurnal Ekonomi dan Bisnis Indonesia, Fakultas Ekonomi UGM

Maddala, G.S \& Kim, I. 1998. Unit roots, cointegration and structural change. Cambridge University Press.

Palaskas T and Harriss B 1993; Testing market integration: a new approaches case material from the West Bengal food economy, Journal of Development Studies, 30:1-57

Patunru, A (2004), Analisis Pasar Beras, Jagung, Kedelai, dan Gula di Indonesia, Laporan Ketahanan Pangan kerjasama Bulog dengan LPEM UI, IPB, PSEKP-UGM

Phillips, P.C.B. \& Perron, P. 1988. Testing for a unit root in time series regression. Biometrica, 75:335346.

Phillips, P.C.B. 1987. Time Series Regression with a Unit Root. Econometrica, 55:277-301.

Ravallion, M 1986; Testing Market Integration, American Journal of 
Agricultural Economics, 68(2): 292-307

Sexton R, C Kling and H Carman, 1991; Market Integration, Efficiency of Arbitrage, and Imperfect Competition: Methodology and Application to US Celery Markets, American Journal of Agricultural Economics, 73: 568-580

Suryana A (1987), The impact of export tax on the palm oil market in Indonesia, Unpublished

Dissertation, North Carolina State University

Sugiyanto, C (2002), The impacts of trade liberalization on the Indonesian palm and coconut oil markets, unpublished Dissertation, University of Illinois

Zanias, G. 1993. Testing for integration in European Community agricultural product markets. Journal of Agricultural Economics, 44:418-427. 


\section{Lampiran}

\section{Uji Stasioneritas}

Variabel Ina

a. Unit root test pada level

Null Hypothesis: INA has a unit root

Exogenous: None

Bandwidth: 11 (Newey-West using Bartlett kernel)

\begin{tabular}{|c|c|c|c|}
\hline & & Adj. t-Stat & Prob.* \\
\hline Phillips-Perron test & & 5.301962 & 1.0000 \\
\hline Test critical values: & $\begin{array}{c}1 \% \text { level } \\
5 \% \text { level } \\
10 \% \text { level }\end{array}$ & $\begin{array}{l}-2.582734 \\
-1.943285 \\
-1.615099\end{array}$ & \\
\hline
\end{tabular}

*MacKinnon (1996) one-sided p-values.

Null Hypothesis: INA has a unit root

Exogenous: Constant

Bandwidth: 13 (Newey-West using Bartlett kernel)

\begin{tabular}{|c|c|c|c|}
\hline & & Adj. t-Stat & Prob.* \\
\hline Phillips-Perron test & & 2.970280 & 1.0000 \\
\hline Test critical values: & $\begin{array}{c}1 \% \text { level } \\
5 \% \text { level } \\
10 \% \text { level }\end{array}$ & $\begin{array}{l}-3.480818 \\
-2.883579 \\
-2.578601\end{array}$ & \\
\hline
\end{tabular}

*MacKinnon (1996) one-sided p-values.

Null Hypothesis: INA has a unit root

Exogenous: Constant, Linear Trend

Bandwidth: 12 (Newey-West using Bartlett kernel)

\begin{tabular}{lrcc}
\hline \hline & & Adj. t-Stat & Prob. $^{*}$ \\
\hline \hline \multicolumn{2}{l}{ Phillips-Perron test statistic } & -0.214808 & 0.9921 \\
\hline \multicolumn{2}{l}{ Test critical values: $\quad$ 1\% level } & -4.029595 & \\
& 5\% level & -3.444487 & \\
& $10 \%$ level & -3.147063 & \\
\hline \hline
\end{tabular}

*MacKinnon (1996) one-sided p-values.

b. unit root test pada 1st difference.

Null Hypothesis: D(INA) has a unit root

Exogenous: None

Bandwidth: 9 (Newey-West using Bartlett kernel)

\begin{tabular}{|c|c|c|c|}
\hline & & Adj. t-Stat & Prob.* \\
\hline \multicolumn{2}{|c|}{ Phillips-Perron test statistic } & -6.074279 & 0.0000 \\
\hline Test critical values: & $\begin{array}{c}1 \% \text { level } \\
5 \% \text { level } \\
10 \% \text { level }\end{array}$ & $\begin{array}{l}-2.582872 \\
-1.943304 \\
-1.615087\end{array}$ & \\
\hline
\end{tabular}

*MacKinnon (1996) one-sided p-values.

Null Hypothesis: D(INA) has a unit root

Exogenous: Constant

Bandwidth: 16 (Newey-West using Bartlett kernel)

\begin{tabular}{lcc}
\hline \hline & Adj. t-Stat & Prob.* \\
\hline \hline Phillips-Perron test statistic & -6.606600 & 0.0000 \\
\hline
\end{tabular}




\begin{tabular}{lcc} 
Test critical values: & $1 \%$ level & -3.481217 \\
& $5 \%$ level & -2.883753 \\
& $10 \%$ level & -2.578694 \\
\hline \hline
\end{tabular}

*MacKinnon (1996) one-sided p-values.

Null Hypothesis: D(INA) has a unit root

Exogenous: Constant, Linear Trend

Bandwidth: 32 (Newey-West using Bartlett kernel)

\begin{tabular}{|c|c|c|c|}
\hline & & Adj. t-Stat & Prob.* \\
\hline \multicolumn{2}{|c|}{ Phillips-Perron test statistic } & -6.207173 & 0.0000 \\
\hline Test critical values: & $\begin{array}{c}1 \% \text { level } \\
5 \% \text { level } \\
10 \% \text { level }\end{array}$ & $\begin{array}{l}-4.030157 \\
-3.444756 \\
-3.147221\end{array}$ & \\
\hline
\end{tabular}

*MacKinnon (1996) one-sided p-values.

\section{Variabel World}

a. Unit root test pada level

Null Hypothesis: WORLD has a unit root

Exogenous: None

Bandwidth: 2 (Newey-West using Bartlett kernel)

\begin{tabular}{lrcc}
\hline \hline & & Adj. t-Stat & Prob. $^{*}$ \\
\hline \hline \multicolumn{2}{l}{ Phillips-Perron test statistic } & -0.223848 & 0.6039 \\
\hline \multicolumn{2}{l}{ Test critical values: $\quad$ 1\% level } & -2.582734 & \\
& 5\% level & -1.943285 & \\
& $10 \%$ level & -1.615099 & \\
\hline
\end{tabular}

*MacKinnon (1996) one-sided p-values.

Null Hypothesis: WORLD has a unit root

Exogenous: Constant

Bandwidth: 2 (Newey-West using Bartlett kernel)

\begin{tabular}{|c|c|c|c|}
\hline & & Adj. t-Stat & Prob.* \\
\hline$\underline{\text { Phillips-Perron test }}$ & & -1.672411 & 0.4429 \\
\hline Test critical values: & $\begin{array}{c}1 \% \text { level } \\
5 \% \text { level } \\
10 \% \text { level }\end{array}$ & $\begin{array}{l}-3.480818 \\
-2.883579 \\
-2.578601\end{array}$ & \\
\hline
\end{tabular}

*MacKinnon (1996) one-sided p-values.

Null Hypothesis: WORLD has a unit root

Exogenous: Constant, Linear Trend

Bandwidth: 3 (Newey-West using Bartlett kernel)

\begin{tabular}{|c|c|c|c|}
\hline & & Adj. t-Stat & Prob.* \\
\hline \multicolumn{2}{|c|}{ Phillips-Perron test statistic } & -3.135746 & 0.1025 \\
\hline Test critical values: & $\begin{array}{c}1 \% \text { level } \\
5 \% \text { level } \\
10 \% \text { level }\end{array}$ & $\begin{array}{l}-4.029595 \\
-3.444487 \\
-3.147063\end{array}$ & \\
\hline
\end{tabular}

*MacKinnon (1996) one-sided p-values. 
b. unit root test pada 1 st difference.

Null Hypothesis: D(WORLD) has a unit root

Exogenous: None

Bandwidth: 9 (Newey-West using Bartlett kernel)

\begin{tabular}{lccc}
\hline \hline & & Adj. t-Stat & Prob.* \\
\hline \hline Phillips-Perron test statistic & -5.243395 & 0.0000 \\
\hline Test critical values: & 1\% level & -2.582872 & \\
& 5\% level & -1.943304 & \\
& 10\% level & -1.615087 & \\
\hline \hline
\end{tabular}

*MacKinnon (1996) one-sided p-values.

Null Hypothesis: D(WORLD) has a unit root

Exogenous: Constant

Bandwidth: 9 (Newey-West using Bartlett kernel)

\begin{tabular}{|c|c|c|c|}
\hline & & Adj. t-Stat & Prob.* \\
\hline \multicolumn{2}{|c|}{ Phillips-Perron test statistic } & -5.215887 & 0.0000 \\
\hline Test critical values: & $\begin{array}{c}1 \% \text { level } \\
5 \% \text { level } \\
10 \% \text { level }\end{array}$ & $\begin{array}{l}-3.481217 \\
-2.883753 \\
-2.578694\end{array}$ & \\
\hline
\end{tabular}

*MacKinnon (1996) one-sided p-values.

Null Hypothesis: D(WORLD) has a unit root

Exogenous: Constant, Linear Trend

Bandwidth: 9 (Newey-West using Bartlett kernel)

\begin{tabular}{lccc}
\hline \hline & & Adj. t-Stat & Prob.* \\
\hline \hline Phillips-Perron test statistic & -5.184465 & 0.0002 \\
\hline Test critical values: & 1\% level & -4.030157 & \\
& 5\% level & -3.444756 & \\
& 10\% level & -3.147221 & \\
\hline \hline
\end{tabular}

*MacKinnon (1996) one-sided p-values.

\section{Estimasi persamaan VAR}

a. Model 1

Vector Autoregression Estimates

Date: 09/17/11 Time: 09:50

Sample(adjusted): 2000:06 2010:12

Included observations: 127 after adjusting

Endpoints

Standard errors in ( ) \& t-statistics in [ ]

\begin{tabular}{ccc}
\hline \hline & $\mathrm{D}(\mathrm{INA})$ & $\mathrm{D}($ WORLD) \\
\hline \hline $\mathrm{D}(\mathrm{INA}(-1))$ & 0.577954 & $-1.24 \mathrm{E}-05$ \\
& $(0.09890)$ & $(2.4 \mathrm{E}-05)$ \\
& {$[5.84381]$} & {$[-0.51046]$} \\
$\mathrm{D}(\mathrm{INA}(-2))$ & -0.281296 & $1.16 \mathrm{E}-05$ \\
& $(0.11188)$ & $(2.7 \mathrm{E}-05)$ \\
& {$[-2.51422]$} & {$[0.42109]$} \\
$\mathrm{D}(\mathrm{INA}(-3))$ & -0.090830 & $2.53 \mathrm{E}-05$ \\
& $(0.11037)$ & $(2.7 \mathrm{E}-05)$ \\
& {$[-0.82293]$} & {$[0.93375]$} \\
$\mathrm{D}(\mathrm{INA}(-4))$ & 0.082582 & $-2.78 \mathrm{E}-05$ \\
& $(0.09605)$ & $(2.4 \mathrm{E}-05)$ \\
& {$[0.85980]$} & {$[-1.17875]$}
\end{tabular}




\begin{tabular}{|c|c|c|}
\hline D(WORLD(-1)) & $\begin{array}{r}628.5672 \\
(373.184) \\
{[1.68433]}\end{array}$ & $\begin{array}{r}0.754558 \\
(0.09161) \\
{[8.23646]}\end{array}$ \\
\hline D(WORLD(-2)) & $\begin{array}{r}-303.4143 \\
(473.569) \\
{[-0.64070]}\end{array}$ & $\begin{array}{r}-0.348602 \\
(0.11626) \\
{[-2.99860]}\end{array}$ \\
\hline D(WORLD(-3)) & $\begin{array}{r}-345.6905 \\
(475.916) \\
{[-0.72637]}\end{array}$ & $\begin{array}{r}0.088878 \\
(0.11683) \\
{[0.76074]}\end{array}$ \\
\hline D(WORLD(-4)) & $\begin{array}{r}281.3843 \\
(383.735) \\
{[0.73328]}\end{array}$ & $\begin{array}{r}-0.078673 \\
(0.09420) \\
{[-0.83515]}\end{array}$ \\
\hline $\mathrm{C}$ & $\begin{array}{r}31.34443 \\
(10.4685) \\
{[2.99417]} \\
\end{array}$ & $\begin{array}{r}0.001411 \\
(0.00257) \\
{[0.54904]} \\
\end{array}$ \\
\hline $\begin{array}{l}\text { R-squared } \\
\text { Adj. R-squared } \\
\text { Sum sq. resids } \\
\text { S.E. equation } \\
\text { F-statistic } \\
\text { Log likelihood } \\
\text { Akaike AIC } \\
\text { Schwarz SC } \\
\text { Mean dependent } \\
\text { S.D. dependent }\end{array}$ & $\begin{array}{r}0.281438 \\
0.232722 \\
1132456 . \\
97.96472 \\
5.777121 \\
-757.7829 \\
12.07532 \\
12.27688 \\
43.79843 \\
111.8390\end{array}$ & $\begin{array}{r}0.403216 \\
0.362756 \\
0.068246 \\
0.024049 \\
9.965796 \\
297.8748 \\
-4.549210 \\
-4.347653 \\
0.002206 \\
0.030126 \\
\end{array}$ \\
\hline $\begin{array}{l}\text { Determinant Resid } \\
\text { Log Likelihood (d. } \\
\text { Akaike Informatior } \\
\text { Schwarz Criteria }\end{array}$ & $\begin{array}{l}\text { Covariance } \\
\text { djusted) } \\
\text { riteria }\end{array}$ & $\begin{array}{r}5.524204 \\
-468.9407 \\
7.668358 \\
8.071471\end{array}$ \\
\hline
\end{tabular}

\begin{tabular}{crr}
\multicolumn{3}{c}{ Korelasi residual (estimasi 1) } \\
& D(INA) & D(WORLD) \\
\hline \hline D(INA) & 1.000000 & -0.068906 \\
D(WORLD) & -0.068906 & 1.000000
\end{tabular}

b. Model 2

Vector Autoregression Estimates

Date: 09/17/11 Time: 10:18

Sample(adjusted): 2000:04 2010:12

Included observations: 129 after adjusting

Endpoints

Standard errors in ( ) \& t-statistics in [ ]

\begin{tabular}{ccc}
\hline \hline & $\mathrm{D}(\mathrm{INA})$ & $\mathrm{D}(\mathrm{WORLD})$ \\
\hline \hline $\mathrm{D}(\mathrm{INA}(-1))$ & 0.578183 & $-1.30 \mathrm{E}-05$ \\
& $(0.09008)$ & $(2.2 \mathrm{E}-05)$ \\
& {$[6.41876]$} & {$[-0.58921]$} \\
& & \\
$\mathrm{D}(\mathrm{INA}(-2))$ & -0.331290 & $2.73 \mathrm{E}-05$ \\
& $(0.08910)$ & $(2.2 \mathrm{E}-05)$ \\
& {$[-3.71819]$} & {$[1.24731]$}
\end{tabular}




\begin{tabular}{lcr} 
D(WORLD(-1)) & 674.9629 & 0.741928 \\
& $(346.621)$ & $(0.08517)$ \\
& {$[1.94727]$} & {$[8.71095]$} \\
& & \\
D(WORLD(-2)) & -468.5244 & -0.307310 \\
& $(350.093)$ & $(0.08603)$ \\
& {$[-1.33828]$} & {$[-3.57233]$} \\
& & \\
& 33.30569 & 0.000627 \\
& $(9.32691)$ & $(0.00229)$ \\
& {$[3.57092]$} & {$[0.27345]$} \\
\hline \hline R-squared & 0.269303 & 0.392000 \\
Adj. R-squared & 0.245732 & 0.372387 \\
Sum sq. resids & 1152287. & 0.069574 \\
S.E. equation & 96.39831 & 0.023687 \\
F-statistic & 11.42523 & 19.98687 \\
Log likelihood & -769.8284 & 302.3313 \\
Akaike AIC & 12.01284 & -4.609787 \\
Schwarz SC & 12.12369 & -4.498942 \\
Mean dependent & 43.48171 & 0.002112 \\
S.D. dependent & 110.9958 & 0.029900 \\
\hline \hline Determinant Residual Covariance & 5.177116 \\
Log Likelihood (d.f. adjusted) & -472.1401 \\
Akaike Information Criteria & 7.475041 \\
Schwarz Criteria & & 7.696732 \\
\hline \hline
\end{tabular}

\begin{tabular}{crc}
\multicolumn{3}{c}{ Korelasi residual } \\
& D(INA) & D(WORLD) \\
\hline \hline D(INA) & 1.000000 & -0.083974 \\
D(WORLD) & -0.083974 & 1.000000
\end{tabular}

3. Penentuan lag optimal

Lag length criteria (estimasi 1)

VAR Lag Order Selection Criteria

Endogenous variables: D(INA) D(WORLD)

Exogenous variables: $\mathrm{C}$

Date: 09/17/11 Time: 10:03

Sample: 2000:01 2010:12

Included observations: 124

\begin{tabular}{ccccccc}
\hline \hline Lag & LogL & LR & FPE & AIC & SC & HQ \\
\hline \hline 0 & -503.9165 & NA & 11.99140 & 8.159943 & 8.205432 & 8.178422 \\
1 & -467.5312 & 71.00997 & 7.112579 & 7.637600 & 7.774065 & 7.693036 \\
2 & -452.9319 & $28.02126^{*}$ & $5.995306^{*}$ & $7.466644^{*}$ & $7.694086^{*}$ & $7.559036^{*}$ \\
3 & -452.6596 & 0.513807 & 6.367802 & 7.526768 & 7.845187 & 7.656117 \\
4 & -451.1257 & 2.845126 & 6.627988 & 7.566544 & 7.975940 & 7.732850 \\
5 & -449.0696 & 3.747404 & 6.841988 & 7.597897 & 8.098270 & 7.801160 \\
6 & -445.1789 & 6.965588 & 6.858254 & 7.599660 & 8.191010 & 7.839880 \\
7 & -444.1728 & 1.768871 & 7.203560 & 7.647948 & 8.330275 & 7.925125 \\
\hline \hline
\end{tabular}

* indicates lag order selected by the criterion

LR: sequential modified LR test statistic (each test at 5\% level)

FPE: Final prediction error

AIC: Akaike information criterion

SC: Schwarz information criterion

HQ: Hannan-Quinn information criterion 
Lag length criteria (estimasi 2)

VAR Lag Order Selection Criteria

Endogenous variables: D(INA) D(WORLD)

Exogenous variables: $\mathrm{C}$

Date: 09/17/11 Time: 10:23

Sample: 2000:01 2010:12

Included observations: 124

\begin{tabular}{ccccccc}
\hline \hline Lag & LogL & LR & FPE & AIC & SC & HQ \\
\hline \hline 0 & -503.9165 & NA & 11.99140 & 8.159943 & 8.205432 & 8.178422 \\
1 & -467.5312 & 71.00997 & 7.112579 & 7.637600 & 7.774065 & 7.693036 \\
2 & -452.9319 & $28.02126^{*}$ & $5.995306^{*}$ & $7.466644^{*}$ & $7.694086^{*}$ & $7.559036^{*}$ \\
3 & -452.6596 & 0.513807 & 6.367802 & 7.526768 & 7.845187 & 7.656117 \\
4 & -451.1257 & 2.845126 & 6.627988 & 7.566544 & 7.975940 & 7.732850 \\
5 & -449.0696 & 3.747404 & 6.841988 & 7.597897 & 8.098270 & 7.801160 \\
6 & -445.1789 & 6.965588 & 6.858254 & 7.599660 & 8.191010 & 7.839880 \\
7 & -444.1728 & 1.768871 & 7.203560 & 7.647948 & 8.330275 & 7.925125 \\
\hline \hline
\end{tabular}

* indicates lag order selected by the criterion

LR: sequential modified LR test statistic (each test at $5 \%$ level)

FPE: Final prediction error

AIC: Akaike information criterion

SC: Schwarz information criterion

HQ: Hannan-Quinn information criterion

4. Uji Stabilitas

a. Uji stabilitas dengan tabel AR roots

Roots of Characteristic Polynomial

Endogenous variables: D(INA) D(WORLD)

Exogenous variables: $\mathrm{C}$

Lag specification: 12

Date: 09/17/11 Time: 10:25

\begin{tabular}{cc}
\hline \hline Root & Modulus \\
\hline \hline $0.234650-0.535137 \mathrm{i}$ & 0.584322 \\
$0.234650+0.535137 \mathrm{i}$ & 0.584322 \\
$0.425405-0.393300 \mathrm{i}$ & 0.579357 \\
$0.425405+0.393300 \mathrm{i}$ & 0.579357 \\
\hline \hline
\end{tabular}

No root lies outside the unit circle.

VAR satisfies the stability condition.

b. Uji stabilitas dengan grafik AR roots

Inverse Roots of AR Characteristic Polynomial

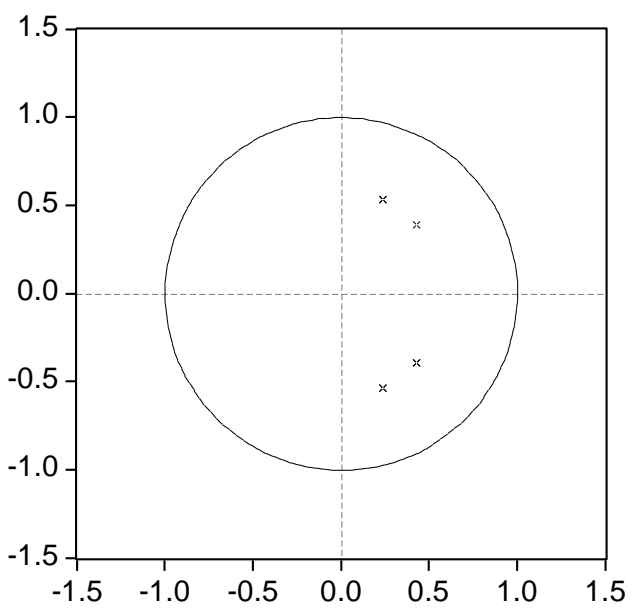




\section{Uji Kointegrasi}

Date: 09/17/11 Time: 10:35

Sample(adjusted): 2000:05 2010:12

Included observations: 128 after adjusting endpoints

Trend assumption: Linear deterministic trend

Series: D(INA) D(WORLD)

Lags interval (in first differences): 1 to 2

Unrestricted Cointegration Rank Test

\begin{tabular}{|c|c|c|c|c|}
\hline $\begin{array}{l}\text { Hypothesized } \\
\text { No. of CE(s) }\end{array}$ & Eigenvalue & $\begin{array}{c}\text { Trace } \\
\text { Statistic }\end{array}$ & $\begin{array}{c}5 \text { Percent } \\
\text { Critical Value }\end{array}$ & $\begin{array}{c}1 \text { Percent } \\
\text { Critical Value }\end{array}$ \\
\hline None $* *$ & 0.247838 & 67.01215 & 15.41 & 20.04 \\
\hline At most $1 * *$ & 0.212372 & 30.55729 & 3.76 & 6.65 \\
\hline
\end{tabular}

$*(* *)$ denotes rejection of the hypothesis at the $5 \%(1 \%)$ level

Trace test indicates 2 cointegrating equation(s) at both 5\% and $1 \%$ levels

\begin{tabular}{ccccc}
\hline $\begin{array}{c}\text { Hypothesized } \\
\text { No. of CE(s) }\end{array}$ & Eigenvalue & $\begin{array}{c}\text { Max-Eigen } \\
\text { Statistic }\end{array}$ & $\begin{array}{c}5 \text { Percent } \\
\text { Critical Value }\end{array}$ & $\begin{array}{c}\text { 1 Percent } \\
\text { Critical Value }\end{array}$ \\
\hline \hline None $* *$ & 0.247838 & 36.45486 & 14.07 & 18.63 \\
At most $1 * *$ & 0.212372 & 30.55729 & 3.76 & 6.65 \\
\hline \hline
\end{tabular}

$*(* *)$ denotes rejection of the hypothesis at the $5 \%(1 \%)$ level

Max-eigenvalue test indicates 2 cointegrating equation(s) at both 5\% and $1 \%$ levels

Unrestricted Cointegrating Coefficients (normalized by $\mathrm{b}^{\prime *} \mathrm{~S} 11 * \mathrm{~b}=\mathrm{I}$ ):

\begin{tabular}{cc}
\hline \hline $\mathrm{D}$ (INA) & $\mathrm{D}$ (WORLD) \\
-0.014274 & 7.495800 \\
-0.001694 & -44.47621 \\
\hline \hline
\end{tabular}

Unrestricted Adjustment Coefficients (alpha):

\begin{tabular}{ccc}
\hline \hline $\mathrm{D}($ INA,2) & 53.86383 & 6.198653 \\
$\mathrm{D}$ (WORLD, 2$)$ & -0.002753 & 0.011833 \\
\hline \hline
\end{tabular}

1 Cointegrating Equation(s): $\quad$ Log likelihood $\quad-479.1881$

\begin{tabular}{cc}
\hline \hline \multicolumn{2}{c}{ Normalized cointegrating coefficients (std.err. in parentheses) } \\
D(INA) & D(WORLD) \\
1.000000 & -525.1334 \\
\multicolumn{3}{c}{$(497.776)$} \\
Adjustment coefficients (std.err. in parentheses) \\
D(INA,2) & -0.768857 \\
& $(0.12251)$ \\
D(WORLD, 2$)$ & $3.93 \mathrm{E}-05$ \\
& $(3.4 \mathrm{E}-05)$ \\
\hline \hline
\end{tabular}




\section{Estimasi Persamaan VECM}

Vector Error Correction Estimates Sample(adjusted): 2000:05 2010:12

Included observations: 128 after adjusting Endpoints

Standard errors in ( ) \& t-statistics in [ ]

\begin{tabular}{|c|c|c|}
\hline Cointegrating Eq: & CointEq1 & \\
\hline D(INA(-1)) & 1.000000 & \\
\hline D(WORLD(-1)) & $\begin{array}{c}-525.1334 \\
(497.776) \\
{[-1.05496]}\end{array}$ & \\
\hline $\mathrm{C}$ & -38.93751 & \\
\hline Error Correction: & $\mathrm{D}(\mathrm{INA}, 2)$ & $\mathrm{D}(\mathrm{WORLD}, 2)$ \\
\hline CointEq1 & $\begin{array}{r}-0.768857 \\
(0.12251) \\
{[-6.27612]}\end{array}$ & $\begin{array}{c}3.93 \mathrm{E}-05 \\
(3.4 \mathrm{E}-05) \\
{[1.16426]}\end{array}$ \\
\hline $\mathrm{D}(\operatorname{INA}(-1), 2)$ & $\begin{array}{c}0.343865 \\
(0.10176) \\
{[3.37916]}\end{array}$ & $\begin{array}{r}-3.61 \mathrm{E}-05 \\
(2.8 \mathrm{E}-05) \\
{[-1.28736]}\end{array}$ \\
\hline $\mathrm{D}(\operatorname{INA}(-2), 2)$ & $\begin{array}{c}0.032785 \\
(0.09470) \\
{[0.34619]}\end{array}$ & $\begin{array}{r}-1.89 \mathrm{E}-05 \\
(2.6 \mathrm{E}-05) \\
{[-0.72482]}\end{array}$ \\
\hline $\mathrm{D}(\mathrm{WORLD}(-1), 2)$ & $\begin{array}{r}384.5180 \\
(315.033) \\
{[1.22056]}\end{array}$ & $\begin{array}{c}0.042812 \\
(0.08681) \\
{[0.49319]}\end{array}$ \\
\hline $\mathrm{D}(\mathrm{WORLD}(-2), 2)$ & $\begin{array}{r}8.740905 \\
(318.107) \\
{[0.02748]}\end{array}$ & $\begin{array}{r}-0.311311 \\
(0.08765) \\
{[-3.55163]}\end{array}$ \\
\hline $\mathrm{C}$ & $\begin{array}{r}3.088506 \\
(8.58349) \\
{[0.35982]} \\
\end{array}$ & $\begin{array}{r}6.78 \mathrm{E}-05 \\
(0.00237) \\
{[0.02865]} \\
\end{array}$ \\
\hline $\begin{array}{l}\text { R-squared } \\
\text { Adj. R-squared } \\
\text { Sum sq. resids } \\
\text { S.E. equation } \\
\text { F-statistic } \\
\text { Log likelihood } \\
\text { Akaike AIC } \\
\text { Schwarz SC } \\
\text { Mean dependent } \\
\text { S.D. dependent } \\
\end{array}$ & $\begin{array}{r}0.349569 \\
0.322912 \\
1150221 . \\
97.09809 \\
13.11356 \\
-764.2439 \\
12.03506 \\
12.16875 \\
3.620859 \\
118.0016 \\
\end{array}$ & $\begin{array}{r}0.124847 \\
0.088980 \\
0.087331 \\
0.026755 \\
3.480844 \\
284.9412 \\
-4.358456 \\
-4.224768 \\
-2.34 \mathrm{E}-05 \\
0.028031 \\
\end{array}$ \\
\hline $\begin{array}{l}\text { Determinant Residu } \\
\text { Log Likelihood } \\
\text { Log Likelihood (d.f } \\
\text { Akaike Information } \\
\text { Schwarz Criteria }\end{array}$ & $\begin{array}{l}\text { Covariance } \\
\text { djusted) } \\
\text { riteria }\end{array}$ & $\begin{array}{r}6.736760 \\
-479.1881 \\
-485.3333 \\
7.802083 \\
8.114024 \\
\end{array}$ \\
\hline
\end{tabular}




\section{Granger Causality}

Dependent Variable: INA

Method: Least Squares

Sample(adjusted): 2000:03 2010:12

Included observations: 130 after adjusting endpoints

\begin{tabular}{lrlrr}
\hline \hline \multicolumn{1}{c}{ Variable } & Coefficient & \multicolumn{1}{c}{ Std. Error } & t-Statistic & Prob. \\
\hline \multicolumn{1}{c}{ C } & -44.17312 & 44.19226 & -0.999567 & 0.3194 \\
INA(-2) & 1.034927 & 0.015855 & 65.27522 & 0.0000 \\
WORLD(-2) & -61.46519 & 196.7913 & -0.312337 & 0.7553 \\
\hline \hline R-squared & 0.987623 & Mean dependent var & 4126.374 \\
Adjusted R-squared & 0.987428 & S.D. dependent var & 1562.463 \\
S.E. of regression & 175.1914 & Akaike info criterion & 13.19244 \\
Sum squared resid & 3897888. & Schwarz criterion & 13.25862 \\
Log likelihood & -854.5087 & F-statistic & 5066.925 \\
Durbin-Watson stat & 0.871050 & Prob(F-statistic) & 0.000000 \\
\hline \hline
\end{tabular}

Dependent Variable: WORLD

Method: Least Squares

Sample(adjusted): 2000:03 2010:12

Included observations: 130 after adjusting endpoints

\begin{tabular}{lrlrr}
\hline \hline \multicolumn{1}{c}{ Variable } & Coefficient & Std. Error & t-Statistic & Prob. \\
\hline C & -0.003707 & 0.012542 & -0.295570 & 0.7680 \\
WORLD(-2) & 0.766522 & 0.055852 & 13.72425 & 0.0000 \\
INA(-2) & $1.61 \mathrm{E}-05$ & $4.50 \mathrm{E}-06$ & 3.568117 & 0.0005 \\
\hline \hline R-squared & 0.838805 & Mean dependent var & 0.248636 \\
Adjusted R-squared & 0.836266 & S.D. dependent var & 0.122878 \\
S.E. of regression & 0.049721 & Akaike info criterion & -3.141959 \\
Sum squared resid & 0.313971 & Schwarz criterion & -3.075786 \\
Log likelihood & 207.2274 & F-statistic & 330.4324 \\
Durbin-Watson stat & 0.519344 & Prob(F-statistic) & 0.000000 \\
\hline \hline
\end{tabular}


8. Impulse Response Function

Response of $D(W O R L D$ ) to Cholesky

One S.D. D(INA) Innovation

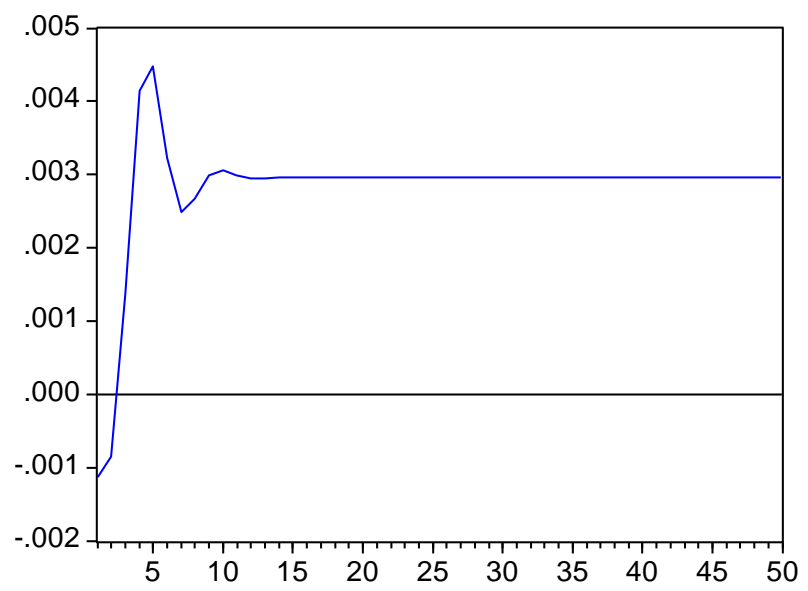

Response of D(INA) to Cholesky One S.D. D(WORLD) Innovation

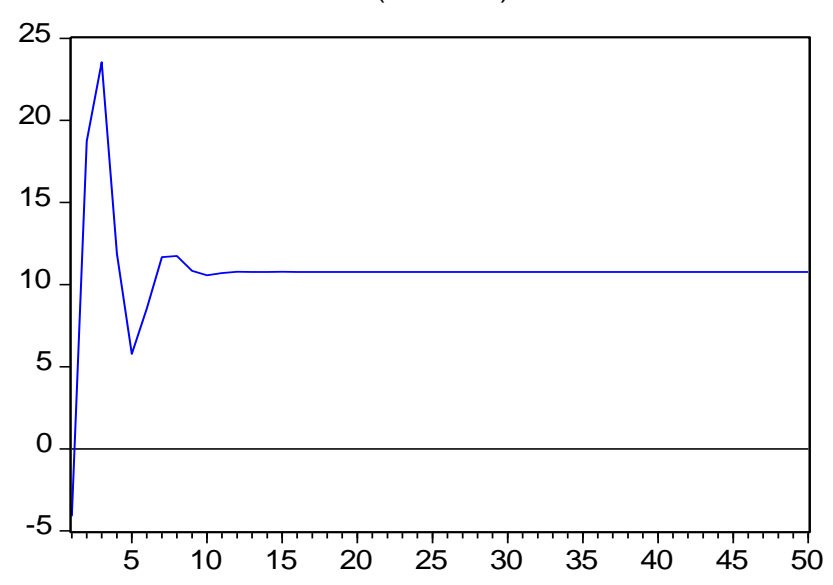

